\title{
The transportation management framework for the Polokwane Local Municipality during the Zion Christian Church Easter weekend pilgrimage
}

\author{
Mathebula, A.M ${ }^{\mathrm{a}}$, Smallwood, J.J ${ }^{\mathrm{b} *}$ \\ ${ }^{a}$ Doctoral student, Department of Contruction Management, Faculty of Engineering, the Built Envirronment and IT,Nelson \\ Mandela University, Port Elizabety, South Africa \\ ${ }^{b}$ Professor, Department of Contruction Management, Faculty of Engineering, the Built Envirronment and IT,Nelson Mandela \\ University, Port Elizabety, South Africa
}

\begin{abstract}
The high volume of traffic to the Holy City of Moria during the Easter weekend could be graphically described as taxing to both the motorists and pilgrims. The rationale for the study was to understand, investigate, analyse and describe the role of the Polokwane Local Municipality (PLM) in the planning and the execution of the Zion Christian Church (ZCC) Easter weekend pilgrimage with a view to reducing vehicular traffic. The PLM is home to the Zion Christian Church (ZCC), that hosts one of the biggest mass gathering event on the African continent, but researchers and the media have paid little or no attention to this pilgrimage which attracts more than 15 million pilgrims during the Easter weekend. It is notable that a mass gathering is an event attended by enough people to strain the planning and response resources of a community, state or nation. The researchers adopted an action research strategy with the view to carving out a lasting solution to the management of the high volume of vehicular traffic during the Easter weekend pilgrimage. Judgemental or purposive sampling was chosen over other available sampling methods due to the few experienced municipality employees who work closely with the church in the planning of the pilgrimage. Eight themes emerged during the interaction between the researchers and the municipality. The study graphically showed that there was a lack of synergy between the ZCC and the municipality in the execution of the pilgrimage. The research findings suggested that; traffic congestion was attributable to a vehicular-centric approach to transport planning in South Africa. The heavy reliance on vehicular transportation by South Africans is a cause of road accidents. The study recommended an introduction of a pilgrim train for the church with a view to reducing vehicular traffic congestion during the Easter weekend pilgrimage for the collective good of both the motorists and the pilgrims.
\end{abstract}

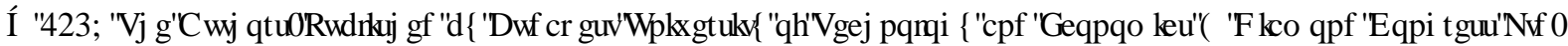

Peer-review under responsibility of the scientific committee of the Creative Construction Conference 2019.

Keywords: Cooperation, Execution, Infrastructure, Planning, Services and Stakeholders.

*Corresponding author: Author email: mabilamabila7@gmail.com 
Mathebula, A.M. and J.J. Smallwood / Proceedings of the Creative Construction Conference (2019) 066 https://doi.org/10.3311/CCC2019-066

\section{INTRODUCTION}

The ZCC's headquarters are at the Zion City Moria, about 25 kilometers east of Polokwane previously known as Pietersburg in the South African Limpopo Province (not to be confused with the underground city, mines and connected tunnels that run through the Misty Mountains in Tolkien's Lord of the Rings). The Polokwane Local Municipality (PLM) and the Zion Christian Church (ZCC) host one of the biggest mass gathering event on the African continent, but researchers and the media have paid little or no attention to this pilgrimage which attracts over 15 million pilgrims during Easter weekend. The number of pilgrims is more than the combined inhabitants of Botswana, Lesotho and Eswatini. Polokwane is a northern Sesotho word that means 'place of safety', but researchers have only focused on the Hajj and the Kumbh Mela as the two-major MG events in the world. Once a year, 3.0 million Muslims from all over the world gather in Mecca to perform the Fifth Pillar of Islam, the Hajj and over 120 million pilgrims attend the Kumbh Mela in India. The Hajj and the Kumbh Mela mass gathering events have received negative media attention due to pilgrims who die on their spiritual journey [1]. For example, in 2015 at least 87 pilgrims died and 184 got injured in Mecca during the Hajj when a construction crane crashed into a mosque. Within a few days, 719 pilgrims died and 800 got injured in a stampede [2].

The Kumbh Mela is replete with several incidents, for example, there has been a fire before the start of Kumbh Mela 2019 in Allahabad, but no one was injured [3]. Another Kumbh Mela devastating event occurred shortly after India gained her independence from Great Britain in 1954, about 1000 people and scores of others were injured whilst the Kumbh Mela in Allahabad was in progress [4]. On the other hand, the Zion Christian Church (ZCC) stands out for its better track record on the safety and the management of the pilgrimage. It is notable that since the church's inception in 1910 hitherto; there has never been a stampede during the pilgrimage, this is thanks to several factors, unalloyed loyalty of the congregants to the faith, the reverential respect which the church members accord their spiritual leader as well as the guardian of the faith and the church values that have been codified into the philosophy of operation. The ZCC pilgrimage receives little academic attention in academic discourse regardless of millions of pilgrims who throng at Zion City Moria (ZCM) in Limpopo every Easter weekend to fulfil their spiritual needs. Historically, the ZCC has been the scoff of society, the Apartheid government and the scientific world. Currently the ZCC is a force to be reckoned with. This muddle-headedness has played down the spiritual importance of the ZCC pilgrimage to its members. The evolution of the ZCC is succinctly captured by the 19th Century philosopher Arthur Schopenhauer who observed that all truth passes through three stages, the ZCC is no exception. First, it is ridiculed. Second it opposed. Third it is accepted as being self-evident [5]. The famous Hebrew poet; King David writes in Psalm 118:22: "The stone which the builders rejected; has become a chief corner stone." [6]. The ZCC has become a chief cornerstone on the African continent and it is currently spreading its wings to other continents.

There is still a big penumbra in literature as to what characterises or constitutes a mass gathering. Researchers oscillate between 1000 and 25000 attendees [7]. The World Health Organisation (WHO) [8] defines a mass gathering as "An organised or unplanned event where the number of people attending is sufficient to strain the planning and resources of the community, state or nation on hosting the event." The ZCC pilgrimage has all the tenants of a mass gathering event according to the WHO definition. First, the event is well planned, as a result, the church uses tried and a tested strategies and tactics to ensure the smooth running of the pilgrimage. Second, the event increases the high volume of traffic on the road which compels the state to deploy more resources such as health workers, emergency workers, traffic and security enforcement officers. Lastly, the event takes place in the province of Limpopo where there is high volume of traffic due to motorist who travel beyond ZCM to their homes in Limpopo as well as other neighbouring countries. The municipality is expected to create a 'temporary city' for pilgrims and to ensure the smooth running of traffic for other motorists. The pilgrims who visit ZCM increase exponentially from year to year basis. For example, during the 2016 Easter Weekend; 12 million pilgrims were hosted at ZCM and during the Easter weekend of 2017, the number of pilgrims increased to 13 million [9]. There is a great likelihood that several pilgrims are likely to reach 16 million in 2019. The buses, mini buses and the private cars are solicitously parked in the Holy City of Moria by the volunteers under the supervision of the church management. After the pilgrimage, the traffic is ushered out of 
Mathebula, A.M. and J.J. Smallwood / Proceedings of the Creative Construction Conference (2019) 066 https://doi.org/10.3311/CCC2019-066

Moria in a systematic way without the church members gate tailing one another. The culture of obedience is paramount amongst the ZCC membership. The following figure is an aerial photo of Moria during the Easter weekend pilgrimage.

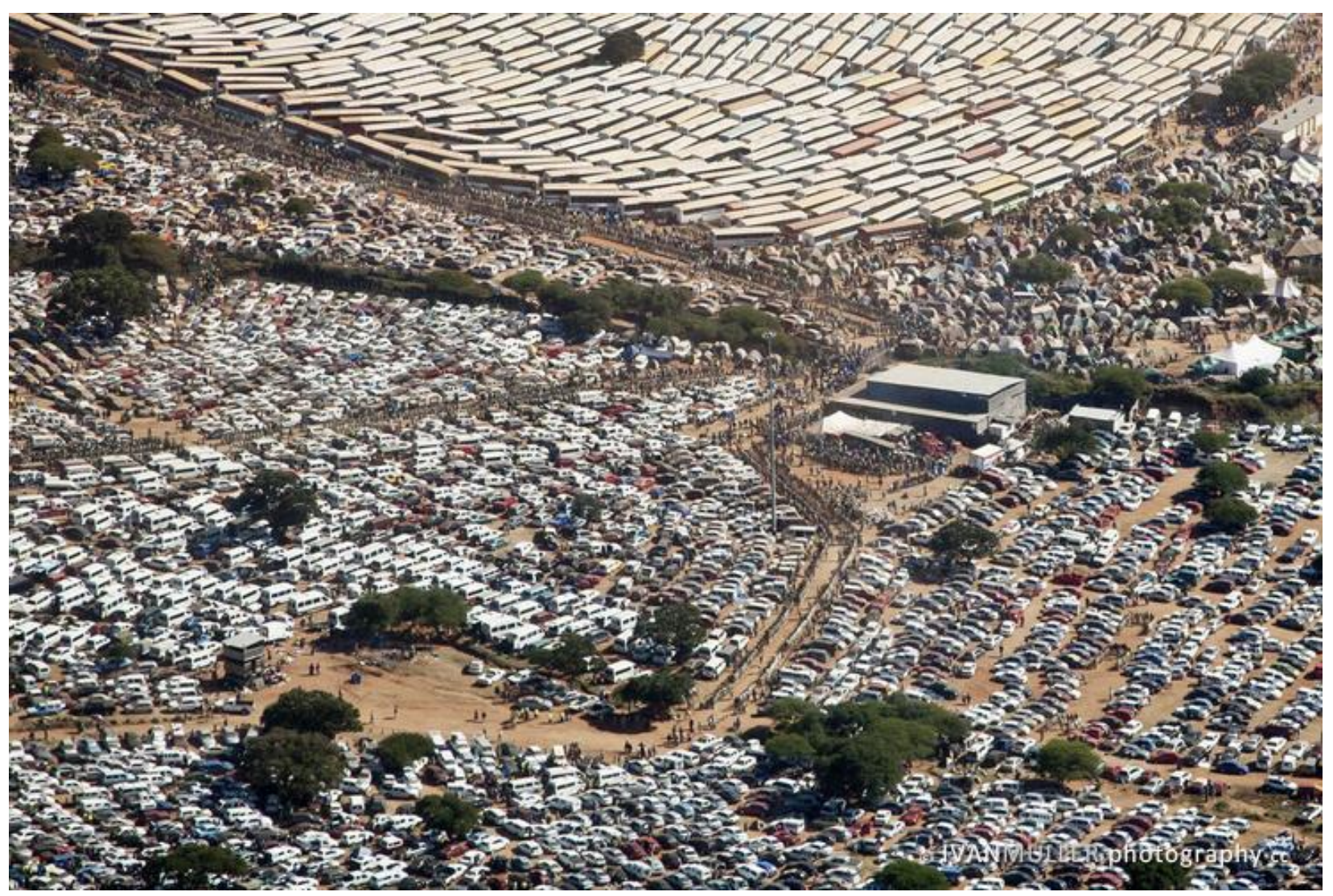

Figure 1: Aerial photo of Moria (photo courtesy of Ivan Muller)

\section{THE OBJECTIVES OF THE STUDY}

The objectives of the study are to identify interventions that will contribute to:

- the designing of a structural framework to manage the pilgrimage during the Easter weekend;

- the carving out of strategies to reduce vehicular traffic congestion during the pilgrimage;

- the engagement of all stakeholders in the planning and execution of the pilgrimage;

- the establishment of how communities around ZCM are affected by vehicular traffic during the pilgrimage;

- the creation of an intermodal transport system during the pilgrimage; and

- creation of awareness of international protocols governing mass gathering events.

\section{PROBLEM STATEMENT}

Although a pilgrimage is an individual's spiritual journey in search of meaning; it ends up as a collective effort on several stakeholders. Hajj, 22:27 states: "And proclaim the Pilgrimage among men; they will come to you on foot and (mounted) on every kind of camel, lean because of journeys through deep and distant mountain highways" (Quran 22:27-30) [10]. Shariati [11] observes that a pilgrimage without people is no pilgrimage at all. The majority of the ZCC use vehicular transport to reach ZCM. The number of pilgrims who visit the Holy City of Moria during the Easter weekend has increases logarithmically since the founding of the church in 1910. During the 2017 Easter 
Mathebula, A.M. and J.J. Smallwood / Proceedings of the Creative Construction Conference (2019) 066 https://doi.org/10.3311/CCC2019-066

weekend pilgrimage, the ZCC hosted an estimate of 13 million pilgrims. The Hajj organisers on the other hand, know in advance the number of pilgrims who would be attending the pilgrimage in Mecca. Both the ZCC pilgrimage and the Kumbh Mela festival which is considered as the "biggest mass gathering on Earth" plan and execute their pilgrimages without a quota management system [12].

According to WHO [13], the organisers of mass gathering events are required to furnish information about how many people will attend a mass gathering event and who they are likely to be. The ZCC will find it increasingly difficult to apply a quota system since it would sound unAfrican to turn visitors away from a place of worship or your home. Africa is laden with such rich heritage or spirituality and cultural diversity, with abounding hospitality and acceptance. The exact number of pilgrims who attend the ZCC Easter weekend pilgrimage would only be known once the pilgrims reach ZCM. Although African hospitality is paved with good intention, it is not beyond critical appraisal. This African approach makes it increasingly difficult for the local government to anticipate the extent to which services must be provided. Simply put, the relationship between the ZCC and the local government should be asymmetrical in the planning and execution of the pilgrimage. The majority of ZCC pilgrims use vehicular transport to reach their ZCM during the Easter weekend and there is no strategy in place to deal with the transit safety of pilgrims at the local municipality level. For instance, traffic congestion causes bottlenecks which makes it increasingly difficult for ambulances, fire extinguishers and police vehicle to move seamlessly during an emergency.

The ZCC Easter pilgrimage creates a huge challenge for both the church and the municipality in creating a temporary city in which millions of people can stay for a period without, injuries, sickness, stampedes, violence and crimes. In addition, the hosting city should ensure that services like transportation, security, water, electricity and sanitation to make the lives of temporary citizens better. The cooperative partnership between the state and mass gathering event organisers is of paramount importance in the management of public health issues. It is inevitable that mass gathering events come at both financial and opportunity costs to the state [14]. Given that the state must ensure the provision of infrastructure and services during mass gathering; the relationship between the organisers and the state should be symmetrical.

The ZCM annually accommodates millions of pilgrims from all the provinces of South Africa, Southern African neighbouring countries and abroad as a result the local municipal system is temporarily disrupted by the number of pilgrims who throng to ZCM. Briefly put, the number of pilgrims outnumbers the permanent residents of Polokwane and thus putting more pressure on the local economy to deliver services such as, traffic management, security management, water supply, drainage services, medical care, law and order with limited or outstretched resources. It is notable that the consumption of these services by pilgrims far outweighs the existing local supply. Put another way, the demand exceeds the supply. Religious mass gathering events expose the pilgrims to numerous health, safety and environmental hazards, such road accidents, the transmission of infectious diseases, physical injuries and impact negatively on local and global health system and services. The role enacted by the state has some shades of grey in the planning and execution of ZCC mass gathering. The state, as the highest societal organisation is, therefore, playing a secondary or reactive role in the planning and execution of this mass gathering event. Often in South Africa, faith-based organisations enact a primary or a proactive role in the planning and execution of mass gathering and delegating all the consequences to the state. Pilgrimage related costs or externalities are automatically internalised by the state long and transferred to the tax payers long after the pilgrimage is over. The volume of traffic during the pilgrimage makes the mobility of the local community difficult since there is no infrastructure that has been designed for the needs of the pedestrians. Put another way, the infrastructure was only designed for the vehicles and nothing was designed for the pedestrians, ignoring the fact that in Africa and in some Oriental countries such as India, walking is a mode of transport for many people.

The ZCC has also experienced a spate of road accidents. In 2011, eleven people died when the bus they were travelling plunged 40 meters down an embankment on the George's Valley Road outside Tzaneen after the driver lost control [15]). Ten people died and 45 were injured when a bus lost control on the NI highway in Polokwane, after the pilgrims attended a church service in Zimbabwe [16]. In 2016, ten members of the ZCC died in a bus crash at George's Valley Road outside Haenesburg near Tzaneen on a Sunday afternoon. The driver lost control of the bus [17]. 
Mathebula, A.M. and J.J. Smallwood / Proceedings of the Creative Construction Conference (2019) 066 https://doi.org/10.3311/CCC2019-066

According to the 2013 International Transport Forum on Road Safety Annual Report, South Africa performed badly in terms of road safety. The report indicated that there were 28 fatalities per 100000 population, which was among the highest rates worldwide in 2011. The economic cost of South Africa's road vehicle accidents is estimated to be R307 billion each year [18].

\section{LITERATURE SURVEY}

The ZCC is growing its membership beyond the African continent; currently there is a branch in England, Saudi Arabia and another one in Canada. Peters [19] notes that in the nineteenth century, many pilgrims who journeyed to Mecca were indigent or enfeebled by age, or the long journey. The health dangers of collecting large crowds of such people in close quarters and often under unsanitary conditions was not regarded as a serious issue, until an epidemic disease appeared in Hijaz in 1865, in the form of cholera. By the time the Hajj was over, 15000 of the estimated pilgrims had died of cholera. In 1893 nearly 33000 pilgrims out of some 200000 died. Dr Oslchanictzki, who was a physician at the time had this to say in an unpublished memoir:

"I was sent from Quamaran to Jidda with a colleague to supervise the return of the pilgrims. All was quiet in the city, but we knew that at Mecca there was a veritable hecatomb of pilgrims; more than a thousand were being reported dead daily. An initial convoy of 5000 camels brought 15000 to Jidda. The ill had to be kept outside the city and only the healthy were admitted."

On 7 February 1894, the ninth International Sanitary Conference was held in Paris to address the Health and Safety of the Mecca pilgrimage. Sixteen countries participated in the conference, including the USA. Western countries who had colonial interests in the oriental world also attended the conference. The conference was exclusively concerned with the Mecca pilgrimage, and specifically the precautions to be taken at ports of departure, the sanitary surveillance of pilgrims traversing the Red Sea, and the sanitary regulations of shipping in the Persian Gulf. The previous International Sanitary Conferences since 1851 insisted on the need not only for sanitary surveillance of the Red Sea and the Persian Gulf, but also for adequate precautions to be applied to pilgrims' ships at their ports of departure [20]. According to Hammoudi (2006) [21], elevators are a major hazard or death trap for the Mecca pilgrims. Pilgrims overload the elevators beyond their capacity. Crowding and shoving lead to overload and when the cable give way, on the fourth or fifth floor, the elevator crashed to the ground and many lives were lost. On the other hand, pilgrims who travel on buses engage in unsafe behaviour. The buses are packed beyond capacity, with pilgrims on the roof, hanging off the steps and rear fenders.

The Constitution of the Republic of South Africa states that the local government is obliged to serve the local community devotedly and concernedly. The following objects of the local government are well articulated in the Constitution of the Republic of South Africa (Act 108 of 1996) [22]:

- to provide democratic and accountable government for local communities;

- to ensure the provision of services to communities in a sustained manner;

- to promote social and economic development;

- to promote a safe and healthy environment; and

- To encourage the involvement of community organisations in the matters of local government.

The Constitution further states that municipalities must (a) structure and manage its administration and budgeting and planning processes to give priority to the basic needs of the community and to promote the social and economic development of the community; and (b) participate in national and provincial development programmes. Sixolo [23] in his M.A dissertation argues that given the background of separate development in South Africa, the prerequisite for municipalities in South Africa is developmental since the country strives to be a developmental state after years of apartness. A developmental municipality will require social cohesion and technical competence. He opines that developmental municipalities will be compelled to consult with their communities in key policy and 
Mathebula, A.M. and J.J. Smallwood / Proceedings of the Creative Construction Conference (2019) 066 https://doi.org/10.3311/CCC2019-066

decision-making initiatives. Briefly put, developmental municipalities require active citizenship. Suliman [24] defines active citizenship as playing a proactive role in your roles and responsibilities towards your society and environment because you are a stakeholder. He argues that making people realise their role as stakeholders in a democratic state is the first step towards active citizenship.

Service delivery protests are commonplace in South Africa. Vatala [25] describes municipalities in South Africa as agencies for service delivery, economic development, tourism, infrastructure development, safety and security, job creation, poverty eradication and environment sustainability. This was enhanced by authors who opine that the role of the local government is to serve the local community [26]. For the local government to enact its role to deliver services to the community, transformation should take place. According to Van Wyk [27], the democratic local government should turn from public administration into a tool for development. The White Paper on Local Government [28] was promulgated as a tool that brings the local government to the people. The White Paper defines local government as a sphere of government that is close to the people, responsible for infrastructure and services that are essential to the wellbeing of the people. It is notable that the services that are provided by the local government to the local community should be the services that the private sector is either unwilling or unable to provide because the services may be delivered on a non-profit or break-even basis [29]. The Municipal System Act (Act 32 of 2000) [30] section 73 (1) zeroes - in on the fact that a municipality must prioritise the basic needs of the community, promote their development and ensure that communities have access to basic services. Reddy [31] argues that local government must embark on programmes that seek to rehabilitate collapsed infrastructure, systems with the view to providing basic services to the community. Caraley [32] argues that the local government is a pivot on which community live rotates, it causes things to happen which may not otherwise happen. On the other hand, local government plays a preventative role, prevent things from happening which may otherwise happen.

\section{RESEARCH STRATEGY: ACTION RESEARCH}

This study was designed in a qualitative dimension. There researchers adopted action research as his strategy. Action research was developed by Kurt Lewin in 1946 [33]. After the researchers have identified their research paradigm as well as the research approach, the next step of the research design is to identify the appropriate research strategy that will lead the researchers to time horizons as well as the data collection process. Saunders [34] identified the following six research strategies namely, experiment, survey, case study, grounded theory, and ethnography and action research. The researchers decided to employ an action research strategy to the study since the researchers could not impose the solution to the organisation under study, but to come up with a collaborative solution. Nieuwenhuis [35] enhances the justification for the action research strategy:

"Definition of action research draw attention to its collaborative or participative dimension and to the focus on a practical problem experienced by participants for which a practical solution is sought. To successfully undertake action research therefore requires an understanding of the context as well as of possible solutions to the problem. Evaluation or assessment of the effectiveness or success of the intervention becomes an important focus in the research. What makes action research a qualitative research type is the strong focus on understanding the problem and developing an intervention with the people involved - it deals with the "why" and the "how" questions."

The aims of action research are better explained by two verbs i.e. action and research, the action component is to bring about radical change in some community or organisation and the research part seeks to increase understanding on the part of the researcher and/or the community or organisation. Dick [36] argues that there are action research methods where the focal point is on action, with research as dividends or a fringe benefit. This study is more on the action rather than on research since its aim of the study is to bring about change in some community or organisation or program. Responsiveness and rigour are the virtues of action research [36]. Reason [37] states the aim of action research is to develop practical solutions in a collaborative manner. There is a difference between the traditional research approaches and the action research approach. 
Mathebula, A.M. and J.J. Smallwood / Proceedings of the Creative Construction Conference (2019) 066 https://doi.org/10.3311/CCC2019-066

The high volume of vehicular traffic to ZCM during the Easter weekend is a challenge to motorists, pilgrims, communities and the three spheres of government. The researchers used the seven-step model proposed by Van Tonder and Dietrichsen [38]. The justification of the model is that it is aligned with the action research model of Organisational Development (OD). It requires that a diagnosis process should be collaborative and participative towards offering solutions to organisational challenges as opposed to imposing a unilateral theoretical generated solution. This model also fits the ontological stance of the researchers which assumes that reality is co-constructed through engagement with other stakeholders.

The researchers purposively or judgmentally selected people who were knowledgeable about the issue under study [39]. Houser [40] opines that convenience sampling has an added benefit over probability samples pertaining to logistics and cost. The following were the key inputs: semi-structured interviews was used to interview the senior management representatives whose responsibilities included the joint planning and the execution of the ZCC pilgrimage, the services and the infrastructure that are provided by the municipality for the smooth running of the pilgrimage were discussed with the senior municipality representative. The PLM also discussed their disaster management plans, traffic flow plans as well as transport planning with the researcher. The rapport building elements are vital in establishing the relationship of trust and credibility during this phase.

The goal of the first phase was to deconstruct and contextualise the ZCC Easter weekend pilgrimage and the level of participation in the pilgrimage by the PLM. The following outputs emerged from this phase: a detailed account of how PLM participants in the ZCC Easter weekend pilgrimage in both ZCC churches, evidence of traffic and disaster management plans, Integrated Development Plan (IDP) as well as the PLM organisational structure with the view to assessing the capacity of the municipality to deliver the biggest pilgrimage on the African continent.

\section{THEMES EMANATING FROM THE ACTION RESEARCH PROCESS}

The following themes were identified throughout the research process:

- Linking transport planning to traffic congestion;

- Pedestrian safety;

- Disaster management;

- Public-private partnership;

- Community involvement;

- Municipal infrastructure and services;

- The use of technology for the pilgrimage;

- Strong church values.

\section{CONCLUSIONS}

The ZCC pilgrimage is the biggest pilgrimage on the African continent. It is notable the church was established in 1910 before the establishment of the PLM when African Independent Churches were looked down upon by the government; as a result, the church developed internal processes to deal with the pilgrimage. The role of the municipality in the planning and the execution of the pilgrimage is secondary in that the church has tried and testes systems in place to manage the pilgrimage. Briefly put, the church employs methods that have worked over the year, but there is always room for improvement. It is also notable that since the establishment of the church in 1910 there has never been a stampede as opposed to other religious gatherings such as the Hajj and the Kumbh Mela. The municipality is incapable of enacting a spiritual role to the community, but they can provide services and infrastructure for the collective good of the community.

It is notable that an African pilgrimage is different from other pilgrimages. For example, a strategy such as the quota system which has been a winning strategy for Hajj to manage the crowds would not succeeds in the context of an African pilgrimage. Africa is synonymous with hospitality; it would be unAfrican to turn people away who intend to pay you a visit based on a quota system. Bishop Barnabas Lekganyane [41]; the spiritual head of the ZCC are worth recalling: "The factor which makes the ZCC the largest spiritual home on the continent is its long-standing understanding of the African culture and social fabric. The church seeks to promote good aspects of African culture while preaching and enhancing the Christian gospel among its members." The central government should also be 
Mathebula, A.M. and J.J. Smallwood / Proceedings of the Creative Construction Conference (2019) 066 https://doi.org/10.3311/CCC2019-066

playing a strategic role by creating a directorate within the DOT to oversee the movement of pilgrims during the Easter weekend; not only the ZCC, but also other denominations such as the International Pentecostal Holiness Church, St Jones and the Nazarene Church and other independent churches throughout South Africa.

The ZCC Easter weekend pilgrimage is dependent on vehicular traffic and the road infrastructure is insufficient to accommodate the pilgrims and other road users who travel to various destinations. The municipality understands this challenge since the number of pilgrims increase exponentially every year, but they lack the financial resources to address this challenge. The root demos in democracy stands for people but the study showed that citizen's participation in the planning and the execution of the pilgrimage is at a very low ebb. The citizens are relegated to the background thanks to the rule-centered culture of the church. This may be perceived as a weakness as well as a strength at the same time in that the church has built its own internal capacity over the years to handle the biggest pilgrimage on the African continent.

The church is an autonomous institution which has been empowered by the Constitution of the Republic of South Africa to exercise religious freedom as stated in Section 15 (1) that states: "everyone has the right to freedom of conscience, religion, thought, belief and opinion." In addition, Section 31 (1) states that "a person belonging to a cultural, religious, or linguistic community may not be denied the right to enjoy their culture, practice their religion and their language." The local government respects the church's belief system, but the belief system does not always chime well with the government approach and protocol. The provincial government and the municipality have the authority to operate and enforce laws outside the Zion City Moria premises; they have got limited say with the internal logistics such as parking as well as hazard identification and risk assessment where the responsibility is taken over by the church. Finally, there are areas where the church and the municipality jointly perform exceedingly well in terms of the pre-planning of the event, traffic management, disaster management as well as the debriefing session after the pilgrimage.

The study graphically demonstrated that the ZCC Easter pilgrimage is a force to be reckoned with in the African continent, but there is still room for continuous improvement in the joint planning and execution of the pilgrimage by both the ZCC and PLM. There are also lessons to be learned from Hajj and the Kumbh Mela since every pilgrimage has its own challenges, for example, pedestrian safety for pilgrim is an acute problem for the Hajj which the ZCC does not experience; it only the PLM that faces pedestrian challenges for the people who live within the vicinity of ZCM. The ZCC and the PLM could also learn from the other pilgrimages on how to manage communicable and non-communicable diseases during the pilgrimage. On the other hand, both the Hajj and the Kumbh Mela could learn the strategies of how to run a stampede free pilgrimage.

\section{RECOMMENDATIONS}

The study has shown that transport planning in South Africa is vehicular-centric. Other modes of transport could reduce the traffic congestion on the roads during Easter weekend. Saudi Arabia has attempted to adopt the proactive approach in their planning process. The government spent SR 6.5 billion to construct the $18 \mathrm{~km}$ Mashir railway line. The Chinese-built monorail links Mecca with holy sites at Mina, Mount Arafat and Muzdalifah. There are 20 trains with a capacity of 3500 pilgrims per trip. The trains transport 72000 pilgrims per hour, and over six hours move 377000 pilgrims from Mecca to Mina, then to Arafat. The number of pilgrims who use the Mashir train has been reduced from its actual capacity of 500000 to 377000 as a safety measure. As an added benefit, the Mashir has created 4000 seasonal jobs for young people to work as security guards. Each train consists of 12 cars with a driver $\mathrm{cab}$ at each end. Each car is equipped with Passenger Information Display System, CCTV and a system to provide audio and visual communications between pilgrims and the train operating staff. These trains are designed to operate in automatic mode (driverless); however, each train has a crew of two drivers and additional passenger attendance available who are there during the Hajj operations (Saudi Railway Commission [42].

In comparison to the South African ZCC gatherings, the Islam Hajj at Mecca appears small. Mecca has the capacity to host only 4 million pilgrims per pilgrimage. Yet, the focus on ensuring the safe passage of the pilgrims has received a far larger focus than is currently the case in South Africa. Herman Bruwer, a South African advisor to the Saudi Railway Safety Commission said that the new system there is "very successful in that it saves the need for almost 53000 buses on site". In his words, "PRASA should consider dedicated trains to Moria, combined with a dedicated bus route available to and from the place of worship". The ZCC should consider building passenger train platforms (at least 20 platforms which is shaded with overhead roofs) on the site which can accommodate at least 20 train coaches each. Each coach should be connected to a fresh water inlet, electricity socket and sewerage system. This way each pilgrim will have access to accommodation, fresh and clean drinking water and sewage for the duration of the pilgrimage. The proposed pilgrimage train should operate from Johannesburg to Polokwane. In addition, a light rail 
system from the Polokwane International Airport to Moria should established with the view to encouraging pilgrims to use airlines as mode of transportation. Many metropolitan areas are addressing transportation needs by establishing light rail transit systems. The ZCC, PLM, the taxi industry, railway companies as well as tolling company should work together towards the establishment of the pilgrim train. Tolling companies should not suffer from the "marketing myopia", they should not see themselves only operating toll gates, but they should also proffer a solution to transport problems in South Africa. Figure 2 is an example of a pilgrim train in Saudi Arabia designed specifically for the Hajj.

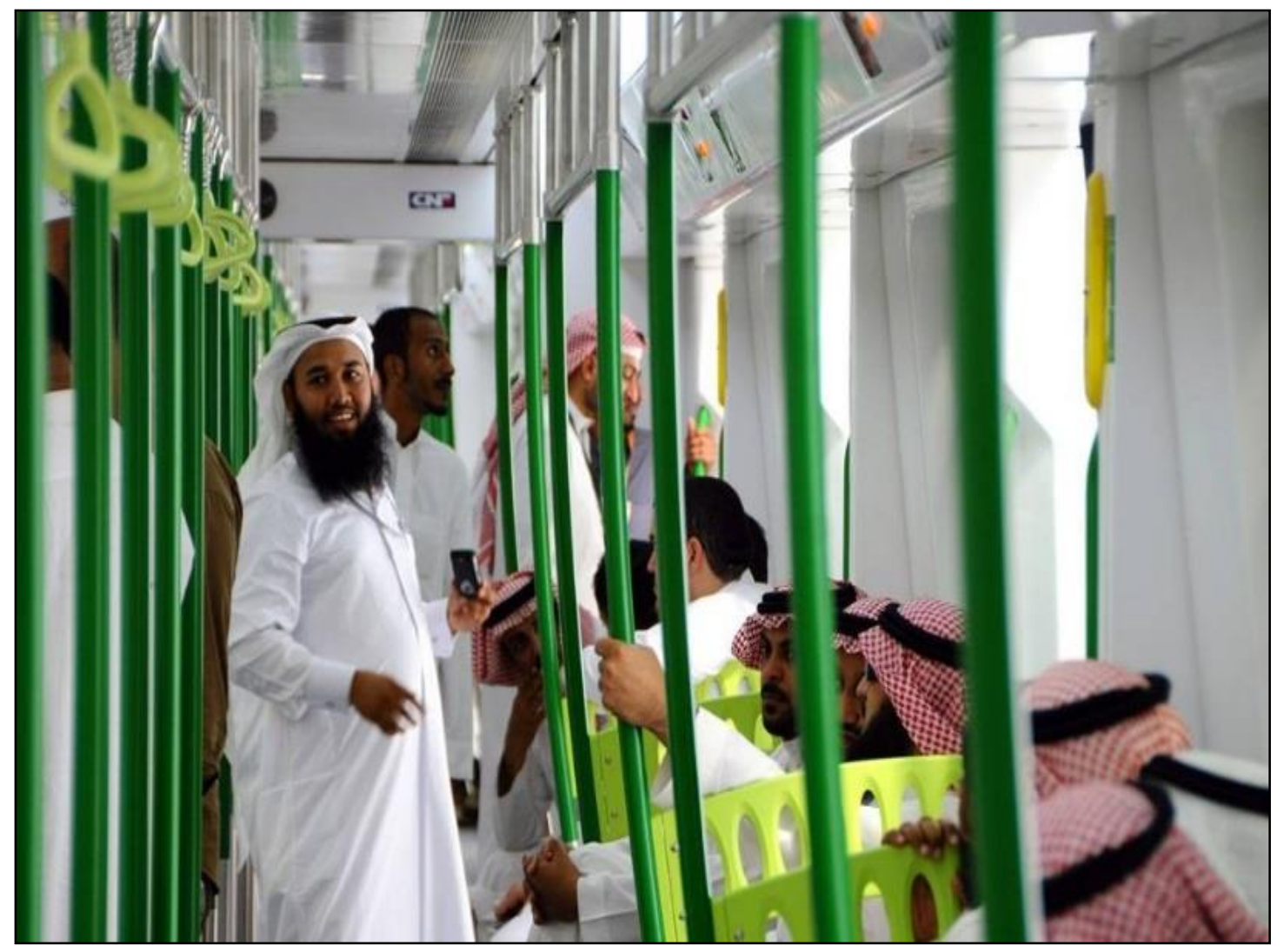

Figure 2: Along the Ride (Photograph by Amer Hilabi, AFP/Getty Images)

The ZCC has been in the transportation business for many years for the collective good of the community. It is highly recommended that the church should opt for vertical integration where they can become both the infrastructure owner and the operator of the train. In so doing, they would be able to create more employment for their members and to make the mobility of their members seamless; not only during the Easter pilgrimage, but throughout the year. Given the history of the ZCC; The Railway Safety Regulator will not hesitate to issue a safety permit to the ZCC.

\section{REFERENCES}

[1]The Guardian, (2006) A history of hajj tragedies, 2006. Available from: http://www.guardian. G.uk/world/2006/Jan/13/Saud Arabia [Date accessed 5 December 2019].

[2]W. Mbhele, No one deserves to die on a spiritual journey, The Sunday Independent, 27 September 2015.

[3]Y.Husain and D. Yusra, Kumbh Mela 2019: Over 16 lakh takes holy dip on Makar Sankranti, 2019. Available from: https: timeofindia.indiatimes.com/city/alahabad/kumbh-begins-today-with-first-shahi-snan-at-daybreak/articleshow/67532198.cms [Date accessed: 3 March 2019].

[4]World Health Organization. Communicable Disease Alert and Response for Mass Gatherings: Key Considerations, Geneva, Swtzerland, June 2008. Available from: http://www.who.int/csr/mass_gathering/en/ [Date accessed 12 November 2018].

[5]C. Handy, The Elephant and the Flea. London, Hutchinson, 2015. 
Mathebula, A.M. and J.J. Smallwood / Proceedings of the Creative Construction Conference (2019) 066 https://doi.org/10.3311/CCC2019-066

[6]T.D. Jakes, Holy Bible: Woman, Thou Art Loosed Edition: New King James Version. Nashville, Thomas Nelson Publishers.,1998.

[7]R.K. Mitchell.,B.R. Agle, D.J. Wood, 1997. Towards A theory of Stakeholder Identification: Defining the principle of who and what really counts. Academy of Management Review.1997, Vol 22 No.4 pp. 853-886. https://doi.org/10.2307/259247

[8]World Health Organization. Public Health for Mass Gathering: Key Considerations,2015. http://www.who.int/lhr/publications/WHO_HSE_GCR_2015.S/en/ [Date accessed 12 November 2018].

[9] Lekganyane, B.E, Bishop Lekganyane Speaks to the Sunday Times. ZCC Massager. Issue No.38 September 1997.

[10]A.Y. Ali, English Translation of The Holy Quran. Durban, Islamic Propagation Centre International, 1943.

[11]A. Shariati, The Hajj. Ohio, Islamic Book Trust,2003.

[12]S.K., Singh, A. Bisht. Environmental Management Mass Gathering: A Case Study of Maha Kumbh Mela 2013 at Prayag, India. International Journal for Innovative Research in Science \& Technology,2014, 1(7), pp. 107-115.

[13] World Health Organization Communicable disease alert and response for mass gatherings: key considerations. World Health Organization, Geneva, 2008.

[14]S. Thackway,T. Churches, J., Fizzel, .D, Muscatello, P,Armstrong, . (2009) Should cities hosting mass gatherings invest in public health surveillance and planning? Reflections from a decade of mass gathering in Sydney:Australia. BMC Public Health, 2009. Available from: http:// www. Biomedentral.com/147/1-2458/9/324 [Date accessed 2 January 2019].

[15]F.Maponya,11 ZCC members die in bus crash Sowetan, 2010. [online] 3 August. Available from: http://www.sowetanlive.co.za/news/2010/08/03/11-ZCC-members-die-in-bus-crash [Date accessed 3 July 2017].

[16] M.Mashaba , Ten Zion Christian Church members die in N1 Road Crash, The Sowetan 7 November 2011.

[17]N.Matlala, New Age. Ten ZCC members die in bus crash. New Age 8 March 2016.

[18]F.Wegman, Road Safety Annual Report. OECD, 2013.

[19]F. E Peters, The Hajj: The Muslim Pilgrimage to Mecca and the Holy Places. New Jersey, Princeton University Press, 1994.

[20]N. Howard-Jones, The Scientific background of the International Sanitary Conference 1851-1938. World Health Organization, Geneva, 1975.

[21]A. Hammoudi, A Season in Mecca: Narrative of a Pilgrimage, New York, Hill and Wang,2005.

[22]Republic of South Africa, The Constitution of the Republic of South Africa. Pretoria, Government Printers, 1996.

[23]L. L Sixolo, An investigation of the role of local government in providing for the needs of the community with specific reference to the Nkonkobe Municipality, Eastern Cape. (M.A.), Nelson Mandela Metropolitan University, 2005.

[24]M. Suliman, Active Citizenship. The Thinker Magazine, 2013, 5 (1), pp.50-51.

[25]S.W. Vatala, Synergies between and Integrated Development Plan, Service Delivery and Budget Implement Plan and other related plans for 2005- 2006 fiscal year. Journal of Public Administration: Conference Proceedings, 2005, pp. 225-233.

[26]G. Van der Waldt, R. Helmbold, The Constitution and a new Public Administration. Kenwyn,Juta and CO. Ltd,1996.

[27]H.A.Van Wyk Perspective of Effective Financial Management in the public sector. Journal of Public Administration 2004,39 (01),pp. 411-9.

[28]Department of corporate Governance and Traditional Affairs , White Paper on Local Government [online]. Department of corporate Governance and Traditional Affairs, 1998. Available from: www.cogta.gov.za/cgta_2016/wp-content/uploads/2016/06/whitepaper _ on _Local Gov_1998.pdf [Date accessed 10 May 2018].

[29]K. Bekker, Citizen Participation in Local Government. Pretoria, J.L. van Schaik Publishers, 1996.

[30]Republic of South Africa, Municipal Systems Act. Pretoria: Government Printers,2000.

[31]P.S. Reddy, Local Government Democratisation and Decentralisation: A Review of the Sothern African Region. Kenwyn, Juta and Co. Ltd, 1999.

[32]D. Carley, City Government and urban problems: A new introduction to urban politics. New York, Prentice-Hall, Inc,1977.

[33]I. Kimhachandra, An Action Research Study of English Teaching in Grade Seven at Bamrug Wittanya School. Nakhon Pathom, Thailand (DEd),Victoria University, 2010.

[34]M. Saunders, P. Lewis, A. Thornhill, Research Methods for Business, third ed, New York, The Free Press,2003.

[35]J. Nieuwenhuis, Qualitative research designs and data gathering techniques. In Maree, K. 16th edition. First Steps in Research. Pretoria, Van Schaik Publishers, 2015, pp 70-92.

[36]B.Dick, Action Research theses. Robust process-paper,1993 pp. 50-2. Available from: http://www.scu.edu.au/schools/gcm/ar/arp/arthesi.htm/ [Date accessed 10 January 2019].

[37]P.Reason, Learning and change through action research. In: J. Henry (Ed), Creative Management. London, Sage,2001. Available from http://www.bath.ac.uk/ mnspwr/paper/Learning Change Through Action Research [Accessed 15 January 2019].

[38]C.L.Van Tonder, C.L. \& P. Dietrichsen, The art of diagnosis. In C.L., Van Tonder \& G. Roodt (eds). Organisational development: theory and practice. Pretoria, Van Schaik, 2008, pp.133-166.

[39]D.F. Polit., C.T.Beck, Nursing Research: Generating Assessing evidence for nursing practice. Philadelphia, Lippincott Williams and Wilkins,2012.

[40]J.Houser, Nursing research reading, using, and creating evidence. Denver, Colorado, Jones and Bartlett Learning, 2018.

[41]B.E. Lekganyane, Bishop Lekganyane Speaks to the Sunday Times. ZCC Massanger,Issue No.38 September 1997.

[42]Saudi Railway Commission, Hajj 1435: Railway Commission Report, 2014. Available from: http://www.witiwand.com/en/Al_Mashaaer_Al_Mugaddassah_Southern_Line [Date accessed 9 February 2017]. 